\title{
ROSALÍA DE CASTRO NA PRENSA. DOUS ESCRITOS PERDIDOS
}

\author{
María Xesús Lama \\ ADHUC, Universitat de Barcelona
}

Resumo: Este artigo presenta dous textos xornalísticos publicados en i870 no periódico ilustrado La Ilustración de Madrid baixo a sinatura R. C. atribuíndo a súa autoría a Rosalía de Castro. Arguméntase cos datos que avalan a identificación da autoría e descríbese o contido dos artigos para interpretar a súa significación como parte da obra da autora, reforzando o seu perfil de escritora profesional.

Palabras-chave: Rosalía de Castro; Gustavo Adolfo Bécquer; Juan Valera; Eduardo Gasset y Artime; Manuel Murguía.

Rosalía de Castro in the press. Two lost Writings

Aвstract: This essay presents two journal articles published in 1870 in the illustrated newspaper La Ilustración de Madrid by R.C., assigning authorship to Rosalía de Castro. This is defended with arguments that support the identification of the author, and further describes the content of the two articles as a means of understanding their significance as part of de Castro's written production, thereby reinforcing her condition as a professional writer.

Keywords: Rosalía de Castro; Gustavo Adolfo Bécquer; Juan Valera; Eduardo Gasset y Artime; Manuel Murguía.

\section{ESCRIBINDO PARA UN PERIÓDICO DIRIXIDO POR BÉCQUER}

Preséntanse a continuación a transcrición de dous textos do periódico La Ilustración de Madrid que aparecen asinados coas iniciais R. C. en dous números de i870 postulando a atribución da súa autoría a Rosalía de Castro. Trátase de dous textos de carácter xornalístico que responden aos requirimentos das colaboracións habituais con que os profesionais da pluma participaban a miúdo na prensa da época, fornecendo contidos de carácter informativo ou cultural para conseguir ingresos máis ou menos inmediatos.

A atribución da autoría baséase nas reiteradas referencias que se encontran na bibliografía rosaliana a unha suposta colaboración da escritora galega

Lama, María Xesús (2019). «Rosalía de Castro na prensa. Dous escritos perdidos». Abriu, 8, 217-237. ISSN: 2014-8526. e-ISSN: $2014-8534$. DOI: I0.1344/abriu2019.8.12. Received: 25/3/2018. Accepted: 4/4/2019. 
nun xornal dirixido por Gustavo Adolfo Bécquer arredor de fins de i869 ou ı870, un dato que acreditaría a relación persoal entre ambos escritores, ou polo menos un coñecemento directo. Os detalles, a través do testemuño da súa filla Alejandra Murguía Castro, aparecen por primeira vez na semblanza de Murguía que elabora Vicente Risco en 1933 para o Seminario de Estudos Galegos (1976: 15), ${ }^{1}$ e posteriormente nun artigo de Martínez Barbeito publicado en La Noche en 1949, baixo o curioso xénero de entrevista reconstruída a partir da memoria que o autor gardaba de conversas que sitúa tamén en 1933, catro anos antes de que ela morrese. Como consecuencia dese testemuño recolle e resume Carballo Calero a cuestión como segue:

[...] cara fins de ı869, ou xa en ı870, coloca Aleixandra o coñecimento de Bécquer. «Coñecimos aos dous irmáns Bécquer». Pero Alexandra dirá a Martínez Barbeito que a Gustavo Adolfo só o viu Rosalía unha vez, malia vivir ambos na mesma rúa de Claudio Coello, il no 7 baixo i ela no I3 terceiro. Carré Aldao negaba toda relación persoal de Rosalía con Bécquer. González Besada semella dar por certo que Bécquer e Rosalía se trataban dende I857. (Carballo Calero 1981: 152)

Mais o relato de Martínez Barbeito sitúa sen dúbida as relacións dos dous escritores no ano i 870 co título contundente: «Ella necesitaba el dinero y él acababa de morir», pois, como é sabido, Bécquer faleceu o 22 de decembro daquel ano. De todos os datos que facilita Alejandra, os únicos que se refiren a lembranzas directas dela e que, polo tanto, poden ser bastante fiables nos detalles, son os relativos a esta estadía en Madrid cando ela tiña once anos, estando Murguía destinado como arquiveiro en Simancas e os meses seguintes a ser destituído daquel posto. Se facemos caso do que contaba Alejandra, segundo a lembranza do xornalista, o trato dos Murguía cos irmáns Bécquer era asíduo e facían proxectos en común xunto cun grupo de amigos, a maioría da súa xeración con renome no mundo xornalístico:

En esta etapa madrileña, hacia finales de I869, Rosalía conoció a Gustavo Adolfo Bécquer, antiguo amigo de Murguía. Otros amigos suyos eran por entonces el es-

- Risco, á súa vez, cita un parágrafo dunha entrevista con Alejandra Murguía atribuída ao xornalista Victoriano Fernández de Asís e publicada no xornal arxentino Correo de Galicia sen concretar a data de publicación. Este sería probablemente o primeiro rexistro do testemuño debido a Alejandra. 
critor andaluz Carlos Rubio, en cuya casa Alejandra Murguía fue presentada al general Prim; Ventura Ruiz Aguilera, que quiso y no pudo hacer a Murguía segundo jefe del museo arqueológico; Julio Nombela, Valeriano Bécquer, Ferrant, Ramón Correa, Fontaura y Federico Ballart. Entre todos estos, más el matrimonio Murguía, pensaron hacer una revista, pero se murió Valeriano Bécquer, que debía ilustrarla, y la revista no se hizo.

A Gustavo Adolfo sólo le vió Rosalía una vez, a pesar de vivir ambos en la misma calle de Claudio Coello, el poeta de las Rimas en el número 7, piso bajo, y la autora de Follas Novas en el 13, piso tercero. Rosalía envió un artículo a la Ilustración española. Necesitaba que se lo pagasen porque llegaban las navidades y su importe vendría muy bien para celebrarlas.

Alejandra fue a cobrarlo a casa de Bécquer y se encontró al poeta lleno de frío, envuelto en mantas y muy enfermo. «No he recibido aún el dinero — le dijo Bécquer-, ya se lo mandaré cuando lo tenga». Al cabo de unos días Rosalía envió de nuevo a Alejandra y esta regresó otra vez con las manos vacías. El poeta acababa de morir. (Martínez Barbeito I949: 2)

Citando de memoria polas súas lembranzas dunha conversa situada dezaseis anos atrás, Martínez Barbeito confunde o nome do xornal onde a escritora tería participado, que non pode ser outro que La Ilustración de Madrid, o que Bécquer dirixía naquel momento. O xornal fora fundado por un amigo da familia Castro, o xornalista e político Eduardo Gasset y Artime (I832-I884), natural de Pontecesures, e deputado sucesivamente por Padrón e Compostela, xa daquela propietario de El Imparcial, quen, ante o éxito da Ilustración Española y Americana fundada en 869 por Abelardo de Carlos, decide, a instancia dos irmáns Bécquer, fundar tamén un diario ilustrado centrado na vida da capital.

Sabemos que coa irmá de Eduardo, Eugenia Gasset, e co pai, o tenente don José Gasset Montaner, fixera Rosalía a súa primeira viaxe a Madrid en I856 (Lama 20ı7: I59 e 173). E tamén sería máis adiante nun xornal de Gasset y Artime, o mencionado El Imparcial, onde publicaría os seus artigos de «Costumbres gallegas». A relación do xornalista con este proxecto ponse de manifesto con claridade no artigo de obituario tras a morte de Valeriano Bécquer: «Bajo los auspicios del Sr. Gasset y Artime se creó La Ilustración de Madrid que dirige D. Gustavo, y en la que D. Valeriano ha dejado trazos admirables de su genio como pintor y su maestría como dibujante» (IM I2/IO/I970: I5). Así mesmo un contemporáneo amigo de todos eles, o escritor Julio Nombela, da fe desta relación nas súas memorias explicando os avatares laborais do seu malogrado amigo Bécquer: 
La revolución de I868 acabó con la fiscalía de novelas, pero Bécquer continuó escribiendo para El Museo Universal, y cuando en I87o fundó Gasset La Ilustración de Madrid, en competencia con La Ilustración española y Americana de Abelardo de Carlos, le confió la dirección literaria del nuevo periódico ilustrado, en el que colaboró con su genial y admirable lápiz su hermano Valeriano. (Nombela i976: 744)

Xa que logo parece evidente a familiaridade de Rosalía de Castro coa redacción e co propietario da revista, polo que resulta probable que contasen coa súa pluma, como escritora que xa tiña un prestixio, cunha serie de obras publicadas ao longo da década anterior, e que se encontraba naquelas datas residindo en Madrid. En busca do artigo que a autora podía ter pendente de cobro na data da morte do director encontramos dúas colaboracións dela e unha, máis próxima ás datas do Nadal, asinada por Murguía.

\section{CRONISTA DA VIDA URBANA}

O primeiro artigo coa sinatura R. C. aparece no número correspondente ao I2 de febreiro, ben ao comezo daquel proxecto xornalístico, se temos en conta que se iniciara o I2 de xaneiro dese mesmo ano e que publica dous números mensuais, sempre nos días I2 e 27. Trátase dun texto breve na páxina 15 a modo de comentario dunha ilustración da páxina 9 que no índice de gravados dese numero figura así identificado: «El lago de Patinadores, de D. Valeriano Becquer». É moi normal na prensa ilustrada destes anos completar as caixas de páxina con ilustracións, que aparecen despois comentadas por xunto nas últimas páxinas. Os comentarios consisten en noticias ou informacións que complementan a ilustración correspondente e con frecuencia aparecen sen asinar. Neste número os comentarios de ilustracións que aparecen desprazados á páxina I5 son os seguintes: «Una calle de la ciudad de Toledo», ilustración de Valeriano Bécquer na p. I2, esta vez comentado e asinado por G. Bécquer; «Naufragio de un falucho de pescadores en la costa de Benidorm» de D. R[afael] Monleón (p. 8), e «Tapices de Goya», onde comenta reproducións de D. José Vallejo tomadas do Museo de Tapices de El Escorial e do Palacio Real de Madrid (pp. I2-13, ambas noticias da redacción sen sinatura). Parece lóxico deducir, polo tanto, que estes textos só levaban sinatura cando eran dalgunha autoría relevante.

As dificultades para coordinar as ilustracións cos textos na composición da páxina, comúns na época, obsérvanse en todo o número, onde aparecen outros 
gravados de Valeriano Bécquer, como os titulados «Labradoras del valle de Amblés. Tipos de Ávila (p. 4) e «Casa de los señores de Castril en Granada» (p. 5), rodeados dun texto de «Recuerdos de una Semana Santa en Roma» asinado por Emilio Castelar, e en cambio comentados máis adiante: o primeiro na páxina 6 asinado por B., tal vez o propio Valeriano Bécquer ou o seu irmán Gustavo, e o segundo na páxina ıo, asinado por Manuel de Góngora.

O texto que asina Castro é una sinxela descrición dun espazo de ocio da cidade, a modo de breve crónica de sociedade, coa peculiaridade de describir unha actividade que se desenvolve nun inusual espazo exterior. Chama a atención a insistencia, tanto ao inicio como ao final do texto, en anunciar unha continuidade para completar a información con maior profundidade no seguinte número, de xeito que as intencións da autora son claras: non só pretende explorar a historia dun espazo urbano asociado con actividades de ocio e recreo, neste caso El Buen Retiro, senón tamén ofrecer unha visión crítica sobre a planificación urbanística da cidade, mesmo facendo propostas sobre intervencións que consideraría necesarias ou recomendables, e por iso alude á «difícil tarea» que está a emprender, que parece anunciar unha serie ao estilo da que os irmáns Bécquer desenvolveran arredor do mosteiro de Veruela, cos gravados de Valeriano e textos de Gustavo Adolfo no xornal El Contemporáneo. Esa continuación do artigo anunciada non se encontra nos números seguintes e podemos deducir que ese ambicioso plan, que lle garantiría unha serie de publicacións, queda fanado por causas que inda nos son descoñecidas.

Cómpre sinalar tamén que no mesmo número aparece un artigo de Víctor Balaguer sobre a historia de Cataluña, co título «El rey don Jaime y el obispo de Gerona» (pp. 6-7) e outro de Roberto Robert titulado «El niño menesteroso» (pp. 7-9), neste caso en forma de conto. Lembremos que Robert é coñecido para os lectores da autora galega pola dedicatoria do «Conto de Vidal» nos Cantares gallegos, onde nos informaba de que ao autor barcelonés «lle gustan os contos e o gallego», e de feito neste breve conto humorístico protagonizado por un neno pobre encontramos a esencia que recollía tamén Castro no seu conto versificado, crónicas ambos de denuncia que retratan a miseria con certo adobo retranqueiro, na liña da narrativa social popular que segue na Península a escola de Eugène Sue.

Así pois temos varios elementos que avalan a interpretación de que as iniciais R. C. corresponden ao nome de Rosalía de Castro, colaboradora neste terceiro número dun xornal que empeza a súa andaina no Madrid de i870. O testemuño da súa filla Alejandra corrobórase coa familiaridade da autora con outros colabo- 
radores da revista que acabamos de ver no número concreto en que aparece o seu texto, de maneira que ten lóxica que contasen coa súa colaboración nun proxecto onde compartía ideas e intereses con outros colaboradores. Coñecemos a relación con Roberto Robert, e tamén con Emilio Castelar, que máis adiante escribe o prólogo para a primeira edición de Follas novas. Canto a Víctor Balaguer, xa traducira ao catalán algúns poemas de Cantares gallegos en ı $866 .{ }^{2}$

Por se aínda quedase algunha dúbida respecto á atribución autorial e á colaboración de Castro no xornal de Gasset y Artime que dirixía Bécquer, mencionaremos un último dato que pode contribuír a confirmar a súa relación próxima co xornal: Murguía publica tamén ese mesmo ano unha serie de prosas líricas no xornal, que aparece baixo o título «Pensamientos» no número de 27 de outubro (pp. 7-16). Trátase dunha serie de fragmentos marcados con números romanos dos cales algúns aparecen con dedicatorias nas que utiliza as iniciais dos nomes para facer referencia a persoas próximas que só para os coñecidos serían fácilmente descodificables: no IV aparece a dedicatoria «A E. C.» seguida dunha loanza á elocuencia de alguén que parece encontrar escasa comprensión nos seus ideais; no VIII, que comeza «jHija mía! ¡mi esperanza», aparece a dedicatoria «A A.», e no XV, dirixíndose a un amigo coas palabras «He dormido bajo tu techo, mi buen poeta», aparece a dedicatoria «A E. P.», de xeito que a correspondencia das iniciais das dedicatorias parece encaixar respectivamente co parlamentario e amigo Eduardo Chao, a filla Alejandra e o poeta Eduardo Pondal. Por outro lado, cómpre notar que a presenza desta última colaboración testemuña una incorporación da pluma de Murguía ao equipo desta publicación oito meses máis tarde que Castro e cun texto inzado de subxectivismo autobiográfico que contrasta co ton profesional e neutro das colaboracións rosalianas, sexa o que sexa o que ámbolos dous datos signifiquen.

\section{Quen SE ATREVE CON DON JUAN VALERA?}

Moito máis interesante é a segunda colaboración de R. C. que aparece, porén, cunha distancia de tres meses, no número correspondente ao iz de maio. Nes-

${ }^{2}$ Lluïsa Julià (2016) estudou con detalle as relacións de Balaguer con Galicia e a función do grupo de escritores da Bisbal d’Empordà na recepción dos Cantares... en Cataluña, así como os posibles contactos de Balaguer con Castro a través de Joan Sitjar. 
te caso trátase dunha semblanza biográfica do escritor e crítico Juan Valera que se extende nas páxinas I5 e i6, para comentar un retrato, gravado asinado por A. Torre, que anuncia desde a primeira plana dese número a atención que se lle vai dedicar ao personaxe. O texto iníciase na páxina i 5 a continuación dun comentario de espectáculos musicais, «Revista musical», asinado polo famoso compositor de zarzuelas Emilio Arrieta, e prolóngase ocupando case toda a páxina i6, que se completa con dous textos anónimos que comentan dous gravados da páxina i2 sen sinatura recoñecible representando estampas que dan idea dos materiais que interesaban ao público e o imaxinario urbano que se proxecta nelas: «Madrid moderno. Palacio del duque de Uceda» e «Noble. Caballo de la propiedad de Sr. Marqués de Valle Umbroso». Imaxes que poden semellar moi aristocráticas, pero que conviven con outras escenas populares coma as da romaría de San Isidro, a misa na antiga praza da Artillería, ou diversas escenas de rúa. E de novo neste número aparecen sinaturas destacadas da época como D. José Amador de los Ríos ou Isidoro Fernández Flórez, que despois será coñecido sobre todo no xornalismo humorístico como Fernanflor.

Toda a prensa da época está inzada deste tipo de presentacións biográficas, que serven para dar a coñecer mellor ou para facer unha loanza a figuras coñecidas da actualidade. Trátase dun xénero xornalístico que Julio Nombela describe moi ben ao explicar a súa serie de «Retratos a la pluma» para La Épo$c a$, encontrando a súa orixe no éxito que tivo o retrato satírico na prensa francesa de man de Eugène de Mirecourt (I8I2-I880), quen pasa revista sen piedade a todas as celebridades do seu tempo. ${ }^{3}$ Ben ao contrario, na variedade hispana o ton parece recibir a marca indeleble do entusiasmo patrio pola mística e tende á haxiografía. Nombela explica perfectamente a transformación do xénero ao decidir el adoptar o contido e non o continente, e o conseguinte efecto:

Fui un retratista de los que agradan porque aciertan a colocar al original en la mejor postura para que resalten sus cualidades y atractivos. Lo que sucede, por regla

3 Mirecourt fixérase famoso ao destapar o mecanismo de producción literaria masiva de Dumas, utilizando o que el denominou «negros». Despois continuou facendo retratos doutros persoeiros da vida política e cultural, primeiro nunha serie de libriños que forma a súa Galerie des contemporaines (1854-1857) e logo no semanario Les Contemporaines, que contiña en cada número un artigo biográfico. 
general, en estos casos es que los favorecidos elogian el buen golpe de vista del pintor, el parecido de la pintura, y juzgando merecérselo todo, no agradecen el optimismo del retratista. (Nombela 1976: 750)

O retrato de Valera que fai Castro, logo, como esixía o canon do xénero neste entorno hispano, é totalmente eloxioso. É moi probable que ademais se correspondese coa opinión máis estendida sobre o personaxe que retrata: tanto entre os contemporáneos como nas xeracións seguintes encóntrase unha aparente unanimidade en recoñecer a Valera como home culto e ponderado, que coñecía varios idiomas e as culturas clásicas, viaxado como diplomático por Europa e América e dotado dun fino espírito crítico. A súa formación e o seu exercicio profesional privilexiados suscitaban sen dúbida admiración e, ademais, como militante inquebrantable do liberalismo, era para a escritora posiblemente un apreciado correlixionario. De feito a primeira parte do retrato dedícase sobre todo a loar o seu labor nos diferentes postos políticos que viña ocupando e mostra un coñecemento detallado dos seus posicionamentos nos debates ideolóxicos de actualidade e nas votacións do congreso en cuestións puntuais de especial simbolismo respecto á integridade ideolóxica.

Valera en 1870 inda non publicara case nada da súa obra de creación, a pesar de ser académico xa desde ı862, e polo tanto o eloxio da súa obra constrúese arredor das súas colaboracións na prensa, ensaios eruditos e traducións que, certamente, xa lle valeran un recoñecido prestixio no campo cultural. E non é menor o significado da súa posición como académico e a atención que merecen os seus discursos desde ese foro.

Outro dato significativo é o título do retrato, pois inda que pareza que non ten nada de particular por conter só o nome do personaxe en que se centra, para o lector de hoxe non pode pasar desapercibido un dato curioso: agora para nós é coñecido o escritor e crítico Juan Valera, pero para os seus contemporáneos o segundo apelido, que viña dunha saga de destacados marinos e militares, non era en absoluto prescindible. Don Juan Valera Alcalá Galiano antes de escribir o groso da súa obra literaria xa era considerado unha autoridade e entrara desde o comezo na vida cultural madrileña pola porta grande, sobre todo por ser sobriño de don Antonio Alcalá Galiano (I789-I865), o máis destacado crítico do seu tempo e liberal notorio. Fora don Antonio autor do prólogo a El moro expósito (1832) do Duque de Rivas, texto considerado como o manifesto do romanticismo español; membro da tertulia La Fontana de Oro, inmortalizada pola primeira novela de Galdós publicada precisamente en I870, 
e autor de textos canónicos para o estudo do dereito constitucional e da historia da literatura do século XVIII, publicados na década dos corenta. A morte deste ilustre liberal adquiriu unha dimensión simbólica porque faleceu dun ictus durante as reunións do Consello de Ministros, no que participaba como Ministro de Fomento, na chamada Noite de San Daniel, o io de abril de i865, con motíns na rúa como consecuencia da revolta de estudantes que protestaban pola expulsión de Emilio Castelar da súa cátedra na Universidade de Madrid. Sendo un liberal clásico defensor da constitución de Cádiz cun historial que o levou ao exilio en Londres e a participar no golpe de Riego, as tensións vividas dentro do goberno do conservador Narváez, que reprimiu con mortos na rúa aquelas protestas en defensa da liberdade de prensa, parecía encontrar a mellor representación no colapso cerebral dun dos mellores oradores daquel tempo (Fontana 2007: 322). A incondicional amizade que mantivo Alcalá Galiano co Duque de Rivas está na orixe da formación do sobriño na carreira diplomática e o consecuente coñecemento de idiomas e do mundo clásico, posto que Valera acompaña ao Duque cando vai de embaixador a Nápoles. E tampouco debe ser casualidade que este fose o director da RAG entre ı862 e ı 865 , cando Valera ingresou como académico. Era este un círculo de relacións que lle quedaba moi lonxe á maioría dos escritores que trataba de gañar a subsistencia loitando por publicar na prensa ou conseguir algún oco no mercado cultural, como Rosalía e Murguía, os irmáns Bécquer, e tantos outros. É, polo tanto, lóxica a homenaxe que lle tributa a revista a Valera, pero probablemente fose difícil encontrar «quen poña o cascabel ao gato», como dixera a propia Rosalía na súa daquela última novela, El caballero de las botas azules (i867). Ela foi quen asumiu ese reto. Non saberemos nunca se, como dicía Nombela, o favorecido, xulgando merecelo todo, considerou quizais insuficiente o reconto dos seus méritos, posto que cando presentou en forma de antoloxía o panorama literario do seu tempo Valera, como rexistrou Azorín, ${ }^{4}$ esqueceu completamente os méritos da escritora galega:

4 Para completar o retrato cómpre sinalar que Azorín, coa perspectiva da distancia temporal, tamén tiña un concepto de Valera ben diferente do que se intentaba propagar na prensa do XIX, e así explica o seu esquecemento de Rosalía na antoloxía: «De Valera, tan frívolo, tan dogmáticamente superficial, no es de extrañar el desdén; con desdén eutrapélico —igual que Campoamor - trató este escritor a pensadores y artistas de cuya idealidad no llegó jamás a enterarse» (Azorín igig: 50). 
En I902, al formar Don Juan Valera su deplorable Florilegio de poesías castellanas del siglo XIX, no incluyó en esa antologia a Rosalía de Castro; hombres anodinos y mujeres insignificantes acoge Valera; ni de una página puede disponer para uno de los más grandes poetas castellanos de la decimonona centuria. En la introducción a ese repertorio nombra Valera a Rosalía, la nombra de pasada, a la par de versificatrices vulgares. (Azorín I9I9: 50)

\section{A IMPORTANCIA DO IRRELEVANTE: ESCRIBIR PROFESIONALMENTE}

De condición tan diferente como son os dous textos aquí recollidos, presentan unha característica común que case me atrevería a definir como «a importancia da súa irrelevancia». Quere isto dicir que son textos de escaso valor intrínseco, que apenas merecen ser tidos en conta no conxunto da obra rosaliana, pero en cambio teñen por iso mesmo un valor extraordinariamente significativo, porque nos mostran a escritora con aspiracións a un exercicio profesional que produce para a prensa do século escritos de circunstancias, mesmo de recheo se é necesario. A que escribe para ter uns ingresos que son importantes para chegar a final de mes, a que se adapta a facer crónicas da vida cotiá, descrición de costumes urbanas ou semblanzas de persoeiros do seu tempo, a que afronta o reto de presentar o crítico que todos temen incomodar e a que mantén as súas relacións nos círculos culturais para que conten coa súa pluma en novos proxectos.

Desvélase con este traballo puramente alimenticio una dimensión da autora que desborda a premisa que dera título ao estudo da faceta xornalística da autora segundo Álvarez Ruíz de Ojeda (20I0), pois en certo modo todas as súas colaboracións coñecidas ata agora trataban temas relacionados con Galicia. Mais aquí descubrimos que a autora tiña outras habilidades para desenvolver unha actividade profesional no ámbito da prensa e que ademais non tiña problema ningún para poñelas en práctica: pode escribir sobre calquera cuestión de actualidade na cidade ou no panorama cultural. Inda que o proxecto quedase pendente, parece ben disposta a documentarse sobre a historia de elementos da paisaxe urbana e manifesta con decisión ter opinión formada sobre a acción política que afecta ao seu entorno, opinión que está presta a expoñer. E desde logo tampouco lle espanta asinar a presentación dun dos persoeiros do momento, con valoracións críticas sobre a súa actividade parlamentaria, a súa obra e o estilo dos seus escritos. Cómpre aquí facer notar que o feito de que a 
semblanza biográfica sexa eloxiosa non implica que estea ausente o compromiso crítico, pois a autora defínese tanto por aqueles a quen censura como a quen loa, e especialmente en tempos tan convulsos politicamente como aqueles anos que seguiron á revolución Gloriosa do i868, definidos pola historia como «sexenio revolucionario».

\section{BIBLIOGRAFÍA CITADA}

Azonín (José Martínez Ruiz) (rigr). Clásicos y Modernos. Buenos Aires: Ed. Losada. Álvarez Ruíz de Ojeda, Victoria (2010). «O labor xornalístico de Rosalía de Castro. A elaboración dunha nova imaxe de Galicia». Aneiros, R., Castro, X., Freixanes, V. (eds.). Xornalistas con opinión II. Vinte biografías. Santiago de Compostela/Vigo: Consello da Cultura Galega/Editorial Galaxia, 67-8I.

Carballo Calero, Ricardo (I98I). Historia da literatura galega contemporánea. Vigo: Galaxia.

Fontana, Josep (2007). La época del liberalismo. Fontana, J./ Villares, R. (eds.). Historia de España, vol. 6. Barcelona: Crítica/Marcial Pons.

IM: La Ilustración de Madrid, Madrid I870-1872 [en liña] [28 marzo 2019]. <http:// prensahistorica.mcu.es/es/consulta/registro.cmd?id=6I33>

Julià, Lluïsa (20I6). «Rosalía de Castro i Catalunya: recepció i debat identitari». Revista de Catalunya, maio, 33 p. [en liña] [28 marzo 20r9].

$<$ http://www.revistadecatalunya.cat/upload/editorial/docPDF-37.pdf>

Lama, María Xesús (2017). Rosalía de Castro. Cantos de independencia e liberdade (1837-1863). Vigo: Galaxia.

Nombela, Julio (1976). Impresiones y recuerdos. Madrid: Ediciones Giner.

Martínez Barbeito, Carlos (1949). «Ella necesitaba dinero y él acababa de morir». Suplemento del sábado de La Noche, 26 de marzo, I-2.

Risco, Vicente (1976). Manuel Murguía. Vigo: Galaxia. 


\section{TEXTO I}

\section{El lago de los patinadores en El Buen Retiro, hoy Parque de Madrid5}

En el lugar correspondiente hallarán nuestros abonados la representación exacta del Lago de Patinadores, recientemente construido bajo la dirección del Sr. Albareda.

En nuestro número próximo publicaremos un detenido artículo sobre la historia del Buen Retiro, mejoras en el actualmente introducidas, y otras que pueden hacerse, y con ese motivo daremos todos los detalles concernientes al grabado que origina estas líneas.

Hoy sólo diremos que el espacio circular del Lago mide ocho mil metros cúbicos. En la época de los hielos servirá para que los aficionados a patinar luzcan su agilidad y firmeza, atrayendo elegantes damas, y ese mundo confortable para quien el frío sólo significa una ocasión en que lucir costosas pieles. En Primavera, verano y Otoño, el lago de Patinadores, cuya profundidad no pasa de una tercia en lo más intrincado de sus abismos, permitirá a la generación menuda infantil entregarse a pueriles juegos marítimos, sin temor a catástrofes y bajo la tierna mirada de los autores de sus días o la mercenaria y responsable de sus ayas y damas de compañía.

Habiendo tenido el Ayuntamiento la galantería de permitir la entrada de carruajes, cuando las calientes brisas de la Primavera cubran de menudo césped y flores la isleta del centro y las pendientes del lago, que colocado sobre una altura domina el horizonte, aquel sitio formará un delicioso lugar de recreo y un paseo sin rival en Madrid, y con muy pocos en otras capitales de Europa.

Pero nos extendemos demasiado. En nuestro próximo número procuraremos satisfacer a nuestros lectores, única aspiración que nos anima y sostiene en la difícil tarea que hemos emprendido.

R. C.

La Ilustración de Madrid (12/2/1870: 15)

5 O gravado do mesmo título na páxina 9. 


\section{TEXTO 2}

\section{Juan Valera y Alcalá Galiano 6}

Constantes en nuestro propósito de engalanar nuestra revista con los retratos de celebridades contemporáneas, faltaríamos a nuestro deber si no nos apresurásemos a emborronar, pues otra cosa no nos permite la falta de espacio, estos apuntes biográficos sobre la vida literaria, artística y política del Sr. D. Juan Valera, cuyo retrato verán nuestros lectores en el lugar correspondiente.

Si con la atención que se merece y atendiendo a la importancia literaria del Sr. Varela nos extendiéramos, como deseamos, en hacer el análisis de sus muchas producciones y, sobre todo, en fijar su personalidad entre nuestros escritores contemporáneos, no uno, sino muchos artículos necesitaríamos para darle a conocer exactamente. Dotado de una maravillosa memoria y de una asiduidad constante que originan en él gran erudición, considerado el Sr. Valera puramente como bibliófilo y hombre de saber, su puesto está entre los primeros. Pero estas dotes se aquilatan y suben de punto al considerarlas revestidas de las formas del escritor, en cuyo concepto, a nuestro juicio, no tiene rival el Sr. Valera, pudiendo colocarse su fácil, galana, correcta y elegante prosa al lado de la de Malo por lo concreta y de fray Luis de Granada por lo fácil y fluida. No es el estilo del Sr. Valera anticuado, a modo de habitante del siglo XIX, que el día de Carnaval sale vestido con trusas y jubón, sin ocultar la tirilla inglesa ni el peinado de Prats. Lejos de buscar entre modelos anteriores un disfraz abigarrado y ridículo para sus escritos, el largo y detenido estudio que de ellos ha hecho es sólo en sus obras el punto de partida, la fuente y origen característicos de nuestros idiomas para hablar y pensar a la moderna, sin recurrir a incomprensibles arcaísmos, ni relucir giros y expresiones gráficas, encerrándolo todo dentro de la rica habla castellana y obedeciendo a las eternales leyes del progreso, sin adulterar lo antiguo ni anticuar lo nuevo.

Tal es, a nuestro entender, la exclusiva personalidad del Sr. Valera entre nuestros escritores, cualidad rara, sobre todo, en hombres que se precian de eruditos y

${ }^{6} \mathrm{O}$ gravado do mesmo título na páxina I.

7 Refírese quizais a Ignacio García Malo (1760-18I2), autor da tradución da Ilíada de Homero ao castelán, e da traxedia Doña María de Pacheco, mujer de Padilla (I788). 
que los son efectivamente. El Sr. Valera puede decirse que es el más fácil español de nuestros prosistas.

Pasemos ahora a dar una ligera biografía del original de nuestro retrato.

Nació D. Juan Valera en Cabra (provincia de Córdova) el i8 de octubre de I824, siendo los autores de sus días los Sres. Marqueses de Paniega. Al nacer Valera, su padre D. José, antiguo oficial de marina retirado, se hallaba impurificado por liberal, en cuya situación estuvo mucho tiempo, arraigándose en su hijo con el ejemplo doméstico los principios a que había de profesar culto toda su vida.

En edad apta para ello, estudió filosofía en el seminario conciliar de Málaga, y más tarde cursó leyes en Granada. Por entonces comenzó a escribir versos y a leerlos en el Liceo de dicha ciudad, publicándose algunos en los periódicos del año 4I.

Terminados sus estudios, y siendo el Sr. Istúriz ministro de estado, fue enviado a Nápoles, y al lado de nuestro gran poeta, el Duque de Rivas, de agregado sin sueldo, donde estuvo dos años y medio, con lo que dio principio a su carrera diplomática. Entregado a sus aficiones literarias y al cumplimiento de sus deberes como empleado, continuó hasta el año $5^{8}$ sin tomar parte en la política, siendo sucesivamente agregado con sueldo en Lisboa, secretario de la legación de Río de Janeiro, donde pasó dos años cesante después, hasta el año 54, en el cual fue enviado por el señor Pacheco de secretario a la legación de Dresde, volviendo a los io meses a Madrid de oficial primero de la secretaría, donde permaneció hasta el año 58 , en que electo diputado y queriéndose dedicar a la política con entera independencia, a pesar de ser empleado de carrera, hizo dimisión de su destino, y colocándose en el terreno liberal en que siempre ha figurado, hizo la oposición del gabinete O’Donnell en el Congreso y formó parte de la redacción de El Contemporáneo, defendiendo en él, dentro del partido conservador, la legalidad del partido democrático, la libertad absoluta de imprenta, el reconocimiento del reino de Italia, y sosteniendo diaria y brillantemente polémicas profundas con los partidos de la reacción.

Diputado de una minoría conservadora liberal en el Congreso de los cinco años, sostuvo la proposición para el reconocimiento del reino de Italia, que firmaron progresistas y demócratas.

Desde entonces ha venido figurando el Sr. Varela en la parte más avanzada de los partidos conservadores liberales, siendo con esta tres las veces que ha sido diputado a las Cortes.

A la caída del Ministerio de Narváez, en el año 65, fue individuo de la comisión para la nueva ley electoral, cuyo preámbulo redactó como secretario, 
siendo presidente el Sr. Ríos Rosas (D. Antonio). A poco tiempo fue nombrado ministro plenipotenciario en Frankfort, de cuyo destino hizo dimisión al volver Narváez al poder, continuando en la oposición hasta el triunfo de Setiembre del 68, por la conciliación de los tres partidos, con cuyo suceso entró a desempeñar la subsecretaría de Estado, hasta que hizo dimisión con motivo de haber votado la candidatura del duque de Génova, que a pesar de ser patrocinada por el Gobierno, era combatida por su partido; rasgo de delicadeza digna de la independencia y caballerosidad de su carácter.

Sería interminable la narración de sus trabajos literarios.

Escribió en El Estado y en otros periódicos políticos artículos de crítica, costumbres, etc.

El año 56 contribuyó principalmente a la fundación de una revista, llamada Peninsular, que los literatos portugueses Caldeira, Latino Coelho y otros, ibéricos entonces, publicaron unidos con varios escritores españoles para hacer propaganda y preparar los ánimos a La Unión Ibérica.

Además ha escrito en muchos periódicos de literatura y algo en dos satíricos, El Cócora y La Malva.

Extendido su justo renombre en los círculos públicos y literarios, entró en la Academia Española en i862, donde desde entonces ha leído muchos notables discursos, siendo entre todos un verdadero modelo de estilo, rica dicción y profundos conocimientos, uno Sobre el Quijote y las diversas maneras de comentarle.

También merecen citarse sus dos discursos contestando a los de los Sres. Cánovas y Canalejas, al ingresar estos señores en la Academia.

El año de i 858 publicó un tomo de poesías líricas, modelo de forma, precedido de un prólogo debido a la pluma de D. Antonio Alcalá Galiano.

Poco después vieron la luz pública dos tomos en que se hallan coleccionados sus mejores artículos políticos y literarios, intitulado Estudios críticos.

Hay una clase de trabajos en que el Sr. Varela es inimitable. Nos referimos a sus traducciones en verso o prosa, ya de los clásicos, ya de poetas contemporáneos. La posesión en que se encuentra de su patrio idioma, el dominio que en la forma ha llegado a adquirir, el profundo conocimiento de idiomas extraños, a lo que le han ayudado un poco sus continuados viajes y estancias en diversas capitales de Europa, no sólo le dan una facilidad no común para esta índole de empresas, sino que le permiten salir de ellas airosamente para su fama, y de una manera provechosa para nuestra lengua. 
Prueba de nuestro aserto es la preciosa traducción que del libro del barón de Shack, Poesías de los árabes de España y de Sicilia, ha hecho, y de la cual lleva publicados dos tomos. ${ }^{8}$

Actualmente colabora el Sr. Varela en la Revista de España, donde ha publicado notables artículos, y recientemente uno sobre Faitenrath, célebre literato alemán, y otro titulado Crematística, el primero sorprendente por su erudición, el segundo humorístico, galano y culto como pocos.

También ha explicado algunos domingos en la Universidad un breve resumen de la historia de las religiones politeístas en los antiguos pueblos de Europa, donde se trata el asunto con arreglo a los adelantos modernos, se divulgan noticias que, aunque muy en compendio, son curiosas e interesantes.

Aunque sin detenimiento ni análisis de las obras del escritor, con lo dicho basta para dar una ligera idea de una vida laboriosa, independiente y digna.

Hoy el Sr. Valera se honra con el cargo de diputado constituyente, habiendo sido elegido hace poco presidente de la comisión que ha de emitir dictamen sobre el arreglo de las carreteras del Estado, para cuyo desempeño reúne condiciones especiales.

Nada diremos en estas columnas del hombre político. En cuanto al literato, al hombre de estudio, toda alabanza sería poca, porque hombres como el Sr. Valera son la gala y la ufanía de los que somos sus modestos compañeros.

R. C.

La Ilustración de Madrid (12/5/1870: 15-16)

8 Valera traduce este libro do alemán, e vaino completar cun terceiro volume dous anos máis tarde. Nun interesante prólogo, o escritor expón a súa valoración da poesía árabe negándolle orixinalidade. 


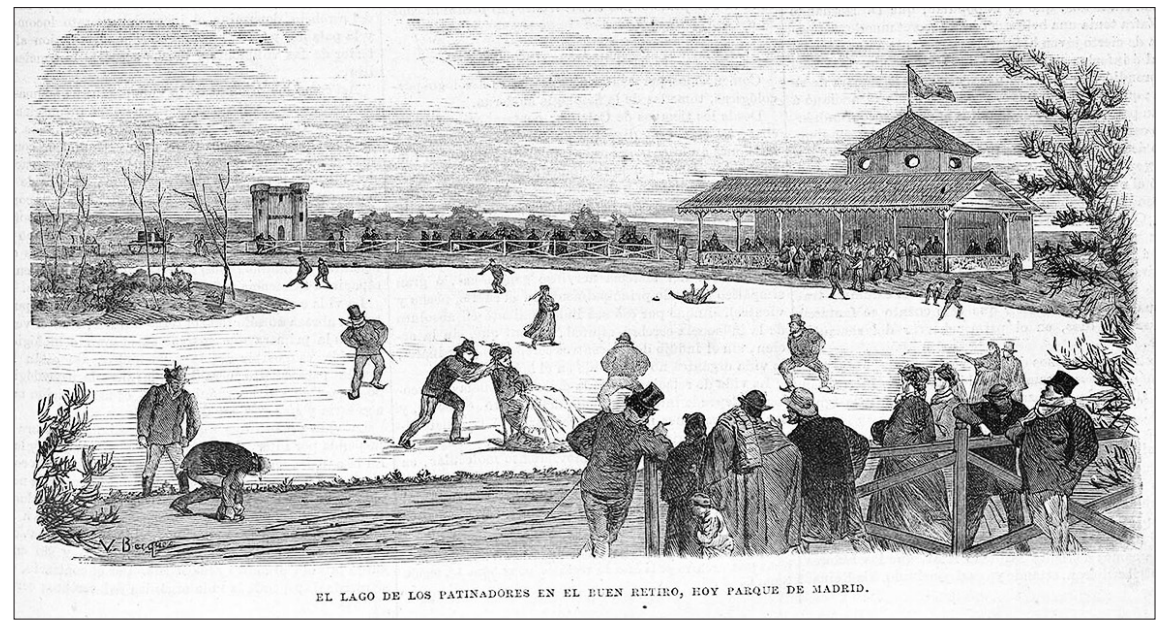

Figura i. Gravado de «El lago de los patinadores», de Valeriano Bécquer. La Ilustración de Madrid (I2/2/1870: 9). 
birse de la curiosidad que su comercio despertaba, seguia llevando todos los diss su carga de verdura al mercado, $\mathrm{y}$ todos los dias tornaba $a$ su choza con buena cosecha do pesetas en el bolsillo, alegre y de sí mismo satisfoch legara el rumor do las hablillas de que era objet que de consuelo le sirviera la gratitud de los arrieros, que, merced a el, tenian agua para sus recuas, a la ena en vano intentaba sustraerse.

XI.

LAS VELADAS DE MELITA.

Entretanto Melita seguia renniendo en su easa todas las noches a crsi toda la poblacion de Valdesuno, cada dia más ansiosa de eseuchar sus cuentos, y haciendo encejes en union de sus discípulos, a la viva luz del caliente hogar

de almarjos.

-Dios guarde á Melita y la compañia, dijo Pedro un noche que tras de muchas de ausencia se presentó en noche, que tras de

-Dios to guarde, Pedro Estudia, contestaron en coro los eircanstantes.

-No me llameis Pedro Estudia, sino Pedro Yasabe Ya sé, Mrelita: los estudios concluyeron, $y$ ahora ya no me falts mis que recoger el frato que dan.

-Pues reeoge, hijo mio, recoge, que yo no me descuido, respondio la encajera sin dejar de mover los pa lillos.

-El año que viene, Melita, creo que podremos hablar de boda.

-Hablaremos, hijo, queá eso está una. Mas echa alarjos en el hogar y siéntate si quiores $a$ oir mis cuientos, que de aqui al año que viene hay muchos dias que

Perico obedeció en silencio con los ojos fijos en la hermosa cara morena de su novia, $y$ la velada prosiguio tranquila y alegre, como desde que Melit.
lones solian ser las veladas de Valdesuno.

XII.

MISTERIOS.

Antes del amanecer del siguiente dia, cuando ol lugar entero áun entregado al sueño estaba, oyóse en su calles el acompasado ruido de muchas carretas, que a lento paso de los graves y sesudos bueyes las atravesaban. Una vieja curiosa, de esas que nunea en los lugares faltan, dejando el caliente lecho $y$ abriendo un postigo de su ventana, púsose a la husma y contó por la mañana d cuantos quisieron oirla, que las carretas hicieron alto frente al caseron que Melita habitaba y que á la luz de un velon con que la encajera salio a la puerta, pudo ver que los carreteros la traspasaxon varias veces sin carg alguna, $\mathrm{y}$ que salieron otras tantes con sendos sacos al hombro 6 rodando barriles, que en sus pesados vehículos cargaron, prosiguiendo despues silenciosamente su marcha. Mas la gente del pueblo, que bien sabia que en el granero do Melita no habia trigo, ni vino eu su bodega, atribuyendo el relato de estos hechos a chocheces de 1 vieje, dib el punto por suficientemente discutido, acordando pasar í otro asunto.

XIII.

iARBOLES:

Un fenómeno sin ejemplo en los anales de Valdesuno tra iaconmovidos y curiosos $i$, aquellos desus habitantes quienes no habia llenado de asombro. Por encima do Fernandez, veíanse algunas ramas nuestro amigo Pedro tones, que vivificados por los rayos de un sol primare ral, pronto se convirtieron en hojas. El soplo primave liev $\delta$ al lugar cantos de pajaros, nuncr en apuo de la brisa ca oidos; que en ella hastr entónces sólo habiella coma los albores del dia alondras y terrerns y otras a a sas que anidan en alondras y terreras y otras aves do o el pobre campesino de y saben vivir sin árboles

XIV.

GACETILLA.

Si en Valdesuno hubiera habido periódicos, poco dias despues de este gran acontecimiento, en alguno de Mllos se veria el suelto siguiente: $L: x$ apreciable encajerc tinjuido conzador vi a contraer matrimonio con el di norrase aun si los Pedro Fernandez, alias Estudia. I lecio que la primerosos pasaran la latra de miel en el pa bella quinta que el segundo posee en esta pintoresca cam- piña. Pero ese poderoso medio de publicidad que selladica, de og femenil se encargo, it falta de prenss porio da, y por esta ver al múnos el períd dico hablado vo al perídico impreso.

(Se conelutiva)

\section{UNA GALLE DE TOLEDO.}

Discurriendo al azar por entre el confuso laberinto calles do la antiquisima ciudad de Toledo erinto historiador y el poeta enenentran en los dotollos do edificios, en los grandes nombres que conmemoran y el sentimiento que inspiran, el más curioso de los museos, la más interesante de.las crónicas y la mís pura fuente de melancolicas y y altas inspiraciones.

El dibujo que damos á nuestros lectores, recuerdo do uno de estos paseos por las desiertas calles do la cindad histórica por excelencia, es cumplida pruebr de lo que dejamos dicho.

En ol fondo ae destaca sobre los redondos arcos del monta al siclo $x$ lo lo y ornato siglo xvr, la torre alta y airosa que en su tip dominacion srabe 1 un la don del sbside de un lue y contra el desaudo pareexpresa con línens mis sobro, se cruz colosal que samiento religios rescos retablos gueno en una epoca de churriguetiguas poblaciones. Al otro, com y la portada de granito de una noblo casa, solar de un esclarecido linage.

El artista no necesita preguntar el nombre de aquellos edificios, ni conocer las circunstancias de su construccion 6 los sucesos de que han sido teatro, para encontra un cuadro completo en la com
sas lineas, su color y detalles.

Pero llega el historiador. Fl nos rofiere que aquel tem
sa plo fá primero mezquita de los moros, los cuales la conservaron dedicada $i$ la celebracion de sas ritos au despues de reconquistada la cindad. Por el sabemo cómo mis tarde se consagró al culto catolico bajo la advocacion de San Roman, que hoy conserra, rosdifićn-
dola y levantando sn airosa torre muzárabe el célebre prócer eastellano D. Estébau de Illar, el cual, ayudado do los Bonavides y de otros caballeros de linages ilustre de Toledo, on una noche del verano de 1116 , despues de haberle sacado ocultamente de la villa de Maqueda, donde lo criaban los secuaces del bando de los Castros, oncerraron en,ella al niño Rey D. Alonso VIUI proclamándolo mayor de edad desde lo alto de sus ajimeces, en los cuales amanecío ondeando el pendon de Castilla, miéntras los heraldos anunciaban la nueva $a$ la atónita poblacion, que no esperaba que sus a

Esta es, nos dice lnego, la casa del famoso D. Fstéban. en la cual es tradicion vivió asimismo ol dulce poet Carcilaso: el tiempo, al borrar el sello de las remotas edades del exterior del edificio, ha respetado en el interior una magnifica sala morisea, ornamentadr conform al gusto muzárnbe tan usado por los conquistadoras, algunos escudos y timbres heráldicos que traen \& las moria el nombre de sus ilustres dueños.

Aquel ábside, añade por último, pertenece al conver to de monjas Bernardas de San Clemente fun convensiglo xIr por D. Alonso el Em Clemente, fundado en redas duerme el sueño de la muerto su hajo cluyas bo D. Fernando.

i Qué grandos proporciones, qué imponente poesia adquiere entónces á nuestros ojos aquella estrecha y solitnria calle que ántes sólo se nos antojaba un cuadro pi toresco, y ya es una pígina viva de nuestra listoria!

G. Becquer.

\section{NAUPRAGIO DE UII BALUCHO DR. PRSCADDRES}

IN XAS COSTAS DE RENIDORM.

Apesar de que durante la última quincená los temporales no han sido tan frecuentes $y$ violentos en muestra costas, como podia temerse, tenemos que lamentar do simiestros, en uno de los cuales han perecido nueve per.

Cerea del islote de Escombrera, en Caitagena, sor-
prendido un falucho por una fuerte racha rino a da prendido un falucho por una fuerte racha, vino á dar sobre la costa próxima, donde la mar lo volcó destrozán-
dolo por completo. Su tripulacion. sin envbargo, des- pues de luchar, aunque inútilmente, con las olas durante algun tiempo, pudo ser socurrida y salvada, merced la aparicion de un bote gnarda-costa, que próximo al lugar de la catístrofe, no vacilo en ír á prestar aynda a Posteriondos náufragos.

Posteriormente, en Benidorm (entre Dénia y Alicante), varios pescadores que se dirigian tambien en un fa. lucho a echar las redes en una almadraba, al doblar ol cabo de la Huerta se acercaron tanto a él, que el barco toeó en un brjo y quodó detenido. En este punto ls mar, que estaba encrespad $n$ y revielta, comenzó $a$ combati liduqu, de modo que los tripulantes casi tenian perdida la esperanza de sacarlo $i$ flote y escapar asi de la muerte. No obstante, lo mismo los pescadores que su mujeres y algunos desgraciedos niños que los acompanaban, cada cual en la medida de sns fuerzas, trabnja ron durante algun tiempo luchando contra el furor de la borrasca; pero esfiuerzos sobrehumanos de los pescadores, rezos de las mujeres y lágrimas y gritos de los nias, todo dir inatil : ana monstraosa ola vino a estrellarso contra el casco, destrozíndolo y envolviéndolo dispersó por entre las peñas á los infelices nánfragos, que unos tras otros fueron pereciendo sin encontrar socorro algano. Nuestro dibujo representa esta desoladora scena, imposible de pintar con palabras.

\section{EL LSGO DR LSS PAIINADORES}

EN EL BUEY RETIRO, HOY PARQUE DE MADRID.

En el lugar correspondiente hallarán nuestros aboriados la representacion exacta del Lago de patinadores, recientemente construido en el Retiro bajo la direccion del Sr. Albareda.

En nuestro número próximo publicaremos un deteni do artículo sobre la historia del Buen Retiro, mejora en el actualmente introducidas, y otras que pueden hacerse, y con este motivo daremos todos los detslles conernientes al grabsido que origina estas lineas.

Hoy sólo diremos que el espacio cirevilar dol Lago mide ocho mil metros cúbicos. En la época de los hielos servir para que los aficionados á patinar luzean sa agi lidad y firmeza, atrayendo elegantes damas y ese mundo confortable, para quien el frio sólo significa una oeasion en que lucir costosas pieles. En Primnvera, Verano Otoño, el Lago de patinadores, cuya profundidad no pasa de una tercia en lo más intrincado de sus abismos, permitirá á la generacion menuda infantil entregarse pueriles juegos marltimos, sin temor a catástrofes bajo la tierna mirada do los autores de sus dias, o la mercenaria y responsable de las ayas y damas de com pañia.

Habiendo tenido el Ayuntamiento la galanteria do permitir la entrada de carruajes, cuando las caliontes brizas de la Primarera enbran de menudo césped y fo res la isleta del centro y las pendientes del lago ane locado sobre una altura domina el horizonte, aquel sitio formará un delicioso lagar de recreo y un paseo sin rival en Madrid, y con muy pocos en otras capitalos do Europa.

Pero nos extendemos demasiado. En nuestro próximo número procuraremos satisfacer $\{$ nuestros lectores, única aspiracion que nos anima y sostiene en la difíeil tarea que hemos emprendido.

i. C.

CARTONES DE GOYA

SUSTRAIDOS DEL PALACIO RFAE DE MMADRID.

No haco mucho hablaron los perídicos de la sustraccion de seis cartones de los varios que pintó Goya para la coleccion de tapices que existia on el Pardo, y qua posteriormente se ha trasladado al nuevo Museo de Ta. pices establecido en el Escorial

La Direccion del Patrimonio que fué de la Corona, despues de practicar las oportunas diligencias asi den tro como fuera de España para recuperar estos notables cartones, ha tenido la feliz idea de mandarlos reproducir, valiéndose para ello de los tapices en que se copiaron, $a$ fin de qus una rez conocido el asunto de los curaros, se haga imposible su venta.

L. ILIsTracion DE MADRID se ha apresurado á secundar esto penzamiento, dando cabida en sus columnas los dibujos que representan los citados cartones, comprendiendo que al par que ayuda a la publicidad de hacho, ofrece á sus lectores una nueva muestra del fácil talento y la gracia de uno de nuestros más populares intores.

Figura 2. Texto de Rosalía de Castro, «El lago de los patinadores». La Ilustración de Madrid (I2/2/I870: I5). 


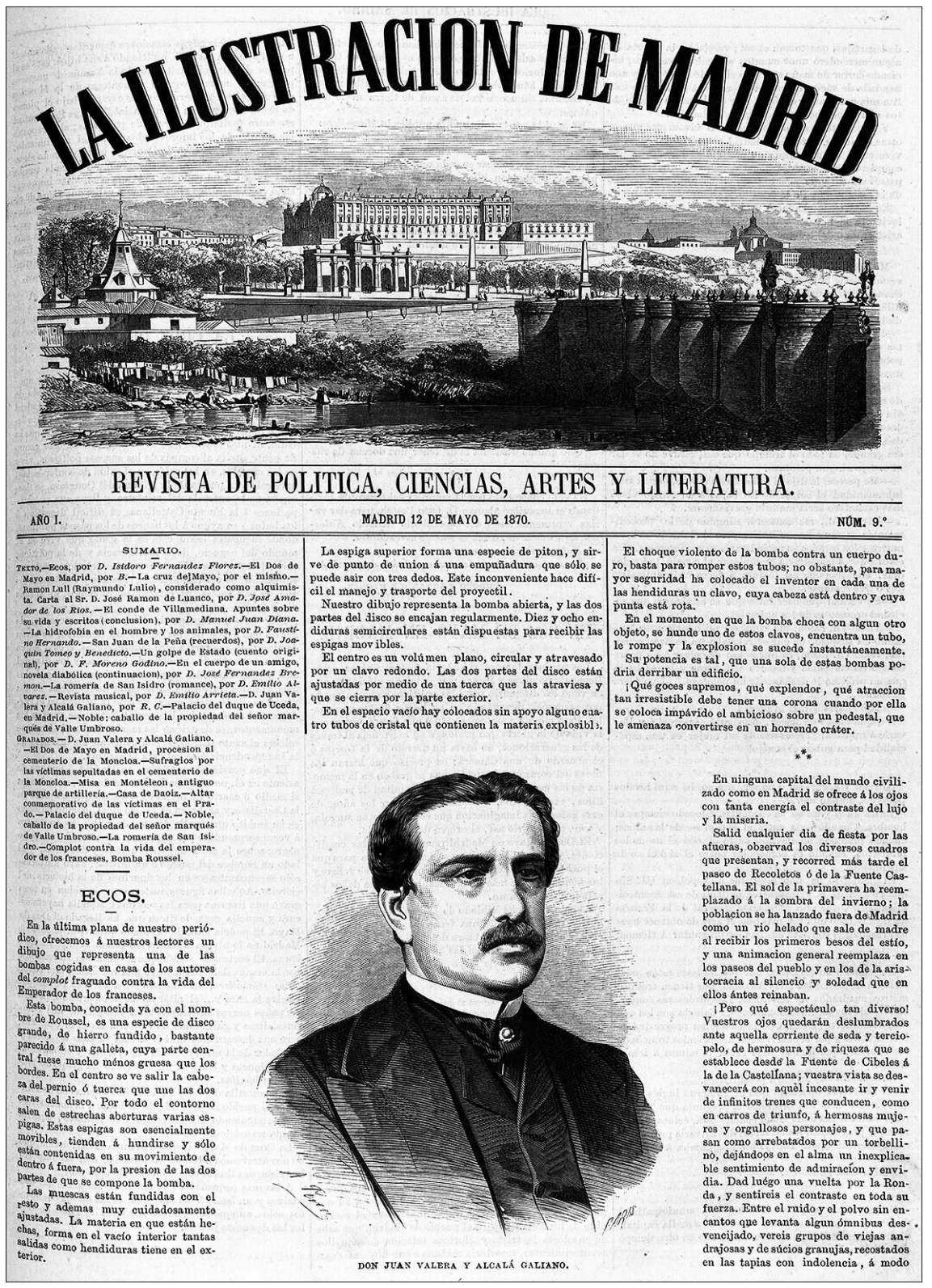

Figura 3. Gravado de «D. Juan Valera Alcalá Galiano», de Alfredo Perea. La Ilustración de Madrid (I2/5/I870: I). 
LA ILUSTRAGION DE MADRID.

$$
\begin{aligned}
& \text { chl Massimo Fattor } \\
& \text { che volle in lui, } \\
& \text { del creator suospirito, } \\
& \text { pit vasta orma stampar., }
\end{aligned}
$$

En Italia suele decirse 4 los que aspiran a cultivar la

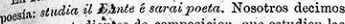
a nuestros estudinitos do composicion, que estudion las obras de Beethoven y llegarán $a$ instrumentar con $m$ tria y $a$ dar vigor y variedad h sus composiciones. Si, futuros compositores, estudiad, estudiad is Beethoven, que

En las obras de Marques, Carreras y Zubiaurre, se rota muchisimo la gran influencia que han ejercido ya, afortunadamento, on nuostra juventad, lns obras olísicas de la escuela alemana que, de ocho años ach sobre todo, con tanta en los grandes conciertos de la Sociedad han ejecutado en los grandes conciertos de la Sociedad de profesores, por cuyo servicio en bien del arte no sonh nuneas.

El señor Narqués nos dio en los conciertos de la primavera dél año pasado una gran sinfonia compuesta en el género $\mathrm{y}$ proporciones de las clísicas, que todos saben el gran Exito que alcanzó, mereciendo el joven autor que le arrojaran una corona en premio de su buen talento $y$ de sa admirable laboriosidad. Este año nos ha dado otra obra de las mismas condiciones: una sinfonía en xr berool dividida en cuatro partes. La $11^{n}$ consta de un, breve andante assai y. un allegro moderat : in
andarte: la $3 .^{n}$ es un scherso; y la $4 .^{n}$ ol finale.

Acometer la composicion de una obra instrunental de tales proporciones, es acometer una empresa sumamente arriesgada. A quien no sucumba en ella, casi puede califichrsele de héroe. Mucho valor se necesita on efecto para eseribir una gran sinfonía con sus cuatro tiempos desarrollados ámpliamente, en esta época en que sin suntrosas decoraciones y. ricos trages, ó corifens que se dietingan por sus relevantes cualidades plásticas, no
gusta la música al vulgo necio! Los que se dediquen a producir estal clase de obras, tienen ademas la desventrja de que nuestra sociedad es enteramente distinta do aquella que conocieron Haydn, Mozart y Bocthoven. Entónces, lo mismo en la casa de un simple particular que en la del noble baron, marqués ó principe, se rendia culto constante i la música instrumental, ya fuese en forma de trio, cuarteto, quinteto, setimino ó sinfonia. Los tres ilnstres autores que acabamos de citar, recibieron las primeras impresiones musicales en el hunilde logar paterno, donde, como se dice ahora, hacian musica los miembros de sus respectivas familias. Ea una ralabra; estaba en las costumbres de aquel tiempo, era una necesidad, el cultivo de la música di cámera. La creacion de la sinfonia por Haydn puede considerrse como uni consecuencia lógica del espíritu filarmonico que dominaba en su époen. A medida que se perfeccionaban artistas y aficionados en la ejecueion de los trios y cuartetos, fueron aumentando el número de instrumentos, hasta llegar $a$ la formacion de la orquesta, para la que compuso el gran maestro sus obras divididas en cuatro partes, cuyo plan ha servido de mode para los compositores sinfonistas que le siguieron. Otros tiempos, otras costumbres. $-\mathrm{La}$ aparicion de una nueva sinfonia a lo Haydn $6 \delta$ lo Beethoven nos causica escrita por un autor dramético una tragedia clàesta la época de las tragedias ni de lnoderno.-No es nías:- Yacen hoy para morir mañana. - La atmúsfera que șe respira es nociva para el producto y para el productor: este se educr en la triste orfandad, $y$ aquel sale álua implorando la earidad en extraña tierra. Sin embargo de esto, siempre merecerán nuestros sinceros elobios los que, como el Sr. Marqués - marchando contra corrients - llegan con felicidad al puerto de sus nobles aspiraciones.

sica, bey disépulos de nuestro Conservatorio de múseñores Marqués, Cacional (como ya hemos dicho), los sibilitados para formar un juicio eritico neerca do sns obras, por considerarnos parte interesada, en atencion $a$ pertenecer nosotros al profesorado de las clases de composicion de aquel establecimiento.

Nos permitirín, pues, nuestros loetores que recurra-
mostablecimiento. mos al ilustrado critico conocido con el pseadónimo de Wruley el abbas, que aunque moro en el nombre, nos par rece muy buen cristiano, para que haga la descripcion y critica de la sinfonia de Marqués, á quien la circunstan cia de ser compositor español le hace acreedor á consideracion tan señalada.

Decia Muley el Abbas hace dias en una do sus nota-
bles revions bles revistas: $\begin{aligned} & \text { "Esta nueva composioion estí formada por un an:lante } \\ & \text { "assai, un allegro moderato, un andante, un scherso y un } \\ & \text { "finale. } \\ & \text { "El andante assai no es sino una oportum? preparacion } \\ & \text { "del alleg o moderato. Este tiempo comicno despues con }\end{aligned} \mid$ "tum motivo de fuga, que exponen las violas y los violon"Cellos, contestando los segundos y los primeros violines "y reproduciéndolos despues toda la orquesta, formando "un crescendo muy lien dispuosto. Este es cl motivo prin"cipal del tiempo en cuestion, que por su carácter seve"ro da á la pieza un sabor puramente.clísico. Siguè des"pues un episodio de menor importancia, pero que con"duce insensiblemente $\{$ una melodín dívina, que cl cla"rinete ejecutan con tal delicadeza y zerdadera pasion, que "se asemeja $A$ la voz de un ángel quế nos habla de amor y llega dulcemente hasta el fondo de nuestós corazo. nes. Con estos motivos juega el autor hasta. In conclusion del tiempo, que la efectúa con el primer motivo pero de una manera grandiosa, haciendo que los trom bones descmpeñen el cinto, lo cual producs un trom, admirable.

-El cindicnte empieza con una frase notable y hermosa sobre la cuarta cuerda de los violines, que va desarro"1líndose por todo el instrumeatal hastállegar a una melodia tierna y apasionada, que interpretan los violines con la mayor perfeccion, repitiendo despies con

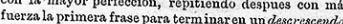
ton opostunnmonto dispuesto, como un icjecutado.

"Este hermoso andante agradó tanto al público, que "pidió su repeticion con el mayor entusiasmo.

iEl scherso y el fiacle son dos piezas ligeras, pero de esmeradisimo trabajo, que en su género agradan tanto como los dos primeros tiempos de la partitura.

"A hora bien: comparada esta sinfonia con la que el mismo antor nos dí á conocer el año pasado, la es el concepto superior, por la mayor igualdad que hay on todos sus tiempos, por sas artisticas proporciones, $y$ "por sa mejor instrumentacion y su brillantez y sonori dad, eireunstancias que demuestran los adelantos heichos por el autor en el género sinfónico.

iReciba nuestros placemes el jóven compositor y no "abandoue la senda que con tanta fortuna ha emprendi
do, saguro de que aleanzan nueros triunfos y su nombre llegarí a figurar al lado del de los más reputados "maestros."

Carreras y Zubiaurre, el primero con su overtura y el egundo con su scherso, han demostrado, y esto es mudio de las obras maestras, podrán llegar con el tiempo i ocupar un puesto distinguido entre los buenos composi-

Nosotros tenemos mucho gusto en felicitarles por haber merecido el honor de que sus composiciones se hayan ejecutado a la vez que las de los grandes maesdós los años en el elegante teatro del paseo de Recodos los

EI señor Espadero, pianista cubano muy notable mug aficionado \& la composicion, es ol autor de Lamer tos del esclav, (escena americana), obra eserita para pia
no y arreglada para orquesta por Monasterio, que se
estrenó eu los conciertos del año pasedo

La primera parte de esta composicion es delicada, melancólica y elegante. La melodía confiada al oboe graciosa y caractaristica; y un pasaje puiangente que desempeñan los primeros violines, que debe pintar talive los Lamentos del esclavo, aunque un si es no os nmane-
rado, tiene novedad y distincion. Lo que no podemos apreciar del mismo modo es lis parte que tiene un ritmo acailable y estín instrumentada para producir un efecto rudo (que si lo produce) y casi salvaje. \&Sera por ventur el momento en que el pobre eselaro sufre sobre su desnudas carnes el látigo sacudido con crueldad inhumana por sa capatäz ó dueño?... Terrible es el asunto; pero la manera do
cruenta y tosca.

Sin ser lo que suponen sus entursiastas admiradore
. cl Sr. Espadero es un verdadero artista, en cuyas com posiciones se encuentran rasgos bellísimos, melódicos y armónicos, $y$ es lástima que la bo
responda $a$ la bondad de las ideas.

En el cuarto concierto so ejecutaron el adargio y el finale, presto del cuartoto en Re (obra 64) do Maydn, por todos los instrumentos de cuerda, y en el sexto la tercera de
mo autor.

Eugenio de Samay dice que la músien de Haydn tiene la tranquilidad del justo; que es sana y que siempre da un buen consejo, á la par que deleita noblemente, y que

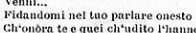

En las dos obras que acabamos de citar se prueba evidentemente la exactitud admirable de este juicio.

Una de las obras que se reprodnjeron eon creciente re sultado fué la overtura de $\mathrm{Bl}$ suerio de una noche de vero, de Mendelssohn.

La gran sinfonia de Strnensée obtuvo un éxito cxDecir que el $\mathrm{Sr}$. conciertos gran intelizencia, y que los profesores $q u$ estín bajo su direcoion no dejaron nada que deses que repetir lo que todo el mundo sabe. Acabemos, pues, es reseña, pasando por alto el ocuparnos de acos, pues, esta turas, ya muy cenocidas de nuestro público por overlas ejecutado repetidas veces la mismo publico por haberque felicitamos con entusiasmo por la poracion, a la campaña que ha hecho este año, con beneplácito de todos los amantes de la buena música. Salad y buena fortuna.

Barriro Arriets.

\section{DON JUAN VALERA Y ALGaLÁ GaliaNo.}

Constantes en nuestro propisito de ongalmar nuestra revista con los retratos de celebridades contemporaneas, faltariamos á nuestro deber si no nos apresurásemos a emborronar, pues otra cosa no nos permite la falta de espacio, estos apuntes biogríficos sobre la vida cuyo retrato verán nuestros lectores en el lugar correspondiente.

Si con la atencion que se mereco y atendiendo $a ́$ la importancia literaria del Sr. Valera nos extendiéramos. como deseamos, en hacer el análisis dé sus muchas produccionos $\mathrm{y}$, sobre todo, en fijar su personalidad entro nuestros escritores contemporáneos, no uno, sino minchos artículos necesitaríamos para darle á conocer matamente. Dutado de una maravillosa memoria y de asiduidad constante que originan en el gran erndicion considerado ol Sr. Valera puramente como erudicion, hombre de saber, su puesto estí entre los primeros. ro estas dotes se aquilatan y suben de punto al considerarlas revestidas de las formas del escritor, en cuyo con. cepto, a nuestro humilde juicio, no tiene rival el $\mathrm{Sr}$. Varecta y elegante prosa al lado de la de Malo por lo concreta, y de la de fray Luis de Granada por lo facil fluida. No es el estilo del Sr. Valera anticuado á modo de habitante del siglo $\mathrm{xrx}$, que en dia de Carnaval sale vestido con trusas y jubon, sin ocultar la tirilla ingle ni el peinado do Prats. Lójos de buscar entre modelog anteriores un disfraz abigarrado $y$ ridiculo mara critos, el largo y detenido estudio que de ellos ha hecho, es sólo on sus obras el punto de partida, la fuento y origen caracteristicos de nuestros idiomas para hablar y pensar $a$ la moderna, sin rocurrir $a$ incomprensibles arcaismos, ni relucir giros y expresiones gráficas, encerrándolo todo dentro de la rica habla castellana, y obedeciendo $a$ las eternales leyes del progreso, sin adulterar lo antiguo ni anticuar lo nuevo.

Tal es, a nuestro entender, la exclusiva personalidad dol Sr. Valera entre nuestros eseritores, cualidad rara, sobre todo, en hombres que so precian de eruditos y que lo son efectivamente. El Sr. Valera puede decirse que es el más fácil español de nuestros prosistas.

Pasemos ahora a dar una ligera biografia del original de nuestro retrato.

Nació D. Juan Valera en Cabra (provincin de Córdoba), el 18 de octubre de 1824, siendo los autores de sus dias los Sres. Marqueses de la Paniega. Al nacer Valera, su padre D. Josó, antiguo oficial de marina retiracion hallaba impierificado por liberal, en cuya situael ejomplo doméstico los principios á que habia de profesar culto toda su vida.

En edad apta para ello, estudió filosofía on el semiEn edad apta para ello, estudio filosofía on el semi-
nario conciliar de Malaga, y más tarde cursó leyes en nario conciliar de Málaga, y más tarde cursó leyes en Granada. Por entónces comenzó a escribir versos y a
leerlos en el Liceo de dicha eindad, publićndose algunos en los periódicos del año 41 .

Terminados sus estudios, y siendo el Sr. Istúriz ministro de Estado, fué enviado á Nápoles, y al lado de nuestio gran poeta, el Duque de Rivas, de agregado s sueldo, dondo estuvo dos años y medio, con lo que dio principio a su carrera diplomática. Eatregado al sus afiempleado politica, siendo sucesivamente agregado con sueldo en

Figura 4. Texto de Rosalía de Castro, «D. Juan Valera Alcalá Galiano». La Ilustración de Madrid (I2/2/1870: I5). 

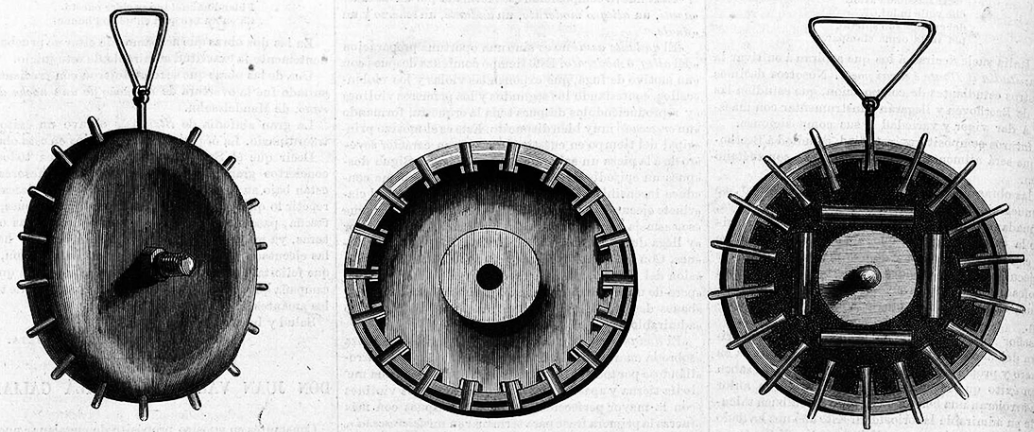

COMPLOT CONTRA LA VIDA DEL RMPERAdOR DE LOS FRANCESEs.-BOMBa ROUSSEL, Mitad DEL TAMASO Naturat.

Lisboa, secretario de la legacion de Rio Janeiro, donde paso dos años cesante despues hasta el año 54 , en el cual fué enviado por el Sr. Pacheco de secretario á la legacion de Dresde, volviendo a los diez meses á Madrid de oficial primero de la secretaria, donde permaneció hasta el año 58 , en que electo diputado y queriéndose dedicar a la politica con entera independencia, apesar de ser empleado de carrera, hizo dimision de su destino, $\mathrm{y}$ colocleado de carrera, hizo dimision en el terreno liberal en que siempre ha figurado, hizo la oposicion del gabinete O'Donnell en el Congreso y formós parte de la redaccion de $E l$ Contemporaneo, de y formo parte de la redaccion de $\mathrm{El}$ Contemporaneo, degalidad del partido democrático, la libertad absoluta do imprenta, el reconocimionto del reino de Italia, y sos teniendo diaria $\mathrm{y}$ brillantemente polémicas profundas teniendo diaris y brillantemente

con los partidarios de la reaccions
Diputado de la minoría conservadora liberal en el Diputado de la minoría conservadora liberal en el
Congreso de los cinco años, sostuvo la proposicion para el reconocimiento del reino de Italia, que firmaron progresistas y demócratas.

Desde entónces ha venido figurando el Sr. Valera e la parte más avanzada de los partidos conservadores liberales, siendo con ésta tres las veces que ha sido diputado á Córtes.

A la caida del ministerio Narvaez, en el año 65 , fu individuo de la comision para la nueva ley electoral, cuyo preámbulo redactó como secretario, siendo presidente el Sr. Rios Rosas (D. Antonio). A poco tiempo fué nombrado ministro plenipotenciario en Francfort de cuyo destino hizo dimision al volver Narvaez al poder, continuando en la oposicion hasta el triunfo de Setiembre del 68, por la conciliacion de los tres partido con cuyo suceso entró a desempeñar la subsecretaría de Estado, hasta que hizo dimision con motivo de habe votado la candidntura del duque de Génova, que apese de sor patrocinada por el Gobierno, era combatida po su partido; raggo de delicadeza digna de la indopendencia y caballerosidad de su carícter.

Soria interminable la narracion de sus trabajos lite rarios.

Escribió en $\mathrm{El} \mathrm{Estado} \mathrm{y} \mathrm{en} \mathrm{otros} \mathrm{periódicos} \mathrm{políticos}$ artíeulos de critica, costumbres, etc.

El año 56 contribuyó principalmente $₫$ la fundacion de una revista, llamada Peninselar, que los literatos de una revistal leira portugueses Caldeira, Latino Coello y otros, ibericos

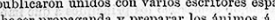
ñoles para hace

Ademas ha escrito en muchos perí́dicos de literatum y algo en dos satíricos, El Cócora y La Malva.

y algo en dos satíricos, Bl Cóora y La Malva.
Extendido su justo renombre en los círeulos públicos Extendido su justo renombre en los circulos publicos
y literarios, entró en la Aeademia Española en 1862, donde desde entónces ha leido muchos notables discursos, siendo entre todos un verdadero modelo de estilo, rica diccion y profundos conocimientos, uno sobre el Quijote y las diversas mazeras de comentarle.

Tambien merecen citarse sus dos discursos contesta do $a$ los de los Sres. Canovas y Canalejas al ingresa

Bl año de 1858 publicó un tomo de poesías líricas, pluma de D. Antonio Alcalá Galiano.

Poco tiempo despues vieron la luz pública dos tomos en que se hallan coleccionados sus mejores articulos políticos y literarios, intitulado Listudios críticos.

Hay una clase de trabajos en que el Sr. Valera es inimitable. Nos reforimos 4 sus traducciones en rerso 6 prosa ya de los clásicos, ya de poètas contemporíneos. La po minio en que se encuentra de su patrio idioma, el do do que en la forma ha llegado 1 adquirir, el profun ayuda ayudado un poco sus continuados viajes y estancias diversas capitales de Europa, no solo le dan una facilidad coman pars esta ndolo do empresas, sino que permiten salir de cllas airosamente para sa fama, $y$ una manera provechosa para nuestra lengua.

dela dell paña y de Sicilia, ha hecho, $\mathrm{y}$ de la cual lleva publica dos dos tomos.

Actualmente colabora el Sr. Valera en La Revista de España, donde ha publicado notables artículos, y recientemente uno sobre Faitenrath, célebre literato aleman, y otro titulado Crematitica, el primero sorprendente de erudicion, el segundo humoristico, galano culto como pocos.

Tambien ha explicado algunos domingos en la Universidad un breve resúmen de la historia de las religiones politeistas en los antiguos pueblos de buropa, donde se trata el asunto con arreglo 6 los adelantos modernos se divulgan noticias que, aunque muy en compendio, son curiosas 6 interesantes.

Aunque sin detenimiento ni análisis de las obras do eseritor, con lo dicho basta para dar una ligera idea. $d$ una vida laboriosa, independiente y digna.

Hoy el Sr. Valera se honra con el eargo de diputado constituyente, habiendo sido elegido hace poco presidente de la comision que ha de emitir dictámen sobre el arreglo en las carreras del Estado, para cuyo desempeño reune condiciones especiales.

Nada diremos en estas columnas del hombre politico. En cuanto al literato, al hombre de estudio, toda alabanza seria poca, porque hombres como el Sr. Valera son la gala y la ufania de los que somos sus modestos compañeros.

\section{MADRID MODERNO.}

PALACIO DEL DUQUE DE UCEDA.

\section{-}

Uno de los caractéres distintivos de nuestra época es el afan de las innovaciones. A este movimiento que en paris ongendro ha debre denoledora que ha hecho celle bre al prefecto Hausuran, obedecen, en mayor 0 menor escala, todos los parses. Al dejar el siglo xix su here pales poblaciones de Europa por el punto topografico que ocupan en el maps. Por fortuna, y para consuelo de sus habitantes, lo que las poblaciones pierden en caricter, originalidad y recuerdos, lo ganan con creces en 39 . lubridad, amplitud y esa especial belleza que resulta de la idea de lo util combinado con lo agradable. Madridese encuentra en este caso. Ha hecho bien el Curios? Pus encuentra en este caso. Ha hecho bien el Curiosn Par. llue on dcjarnos retratados en an libro, merced ‘ 480 pluma, que asl consigna ideas como pinta cuadros com. que que tan ripidamente desaparece de nuestros ojos. A no ser asi, pronto perderiamos modo se trasforma y muda.

No muchas años que entre el paseo de la Fuente Castellana y el Salon del Prado existia, en el punto que se conoce con el nombre de Recoletos, una especie de solucion de continuidad del Madrid elegante.

$\mathrm{La}$ fuente de Cibeles con un triple cintron de cubas y aguadores se destacaba apénas sobre una pared rninosa y mezquina; el Pósito con su fachada polvorista y iscura se alzaba al lado de un callejon formado por la ta. pia de las Salesas, cuyos cipreses altos y oscuros saliendo por cima de las copas raquiticas de algunos pocos ar. boles viejos retorcidos y deformes, daban sombra $\&$ la antigua puerta de Recoletos, cuyas lineas monumenta. les descomponian por un lado el edificio destinado a tescuela de Veterinaria, y por otro tres 6 cuatro miserables casuchas adosadas al monumento.

El municipio, constante en su idea de embellecer ls poblacion, fijo al cabo sus ojos en este punto, $y$ secunda. do por el esfuerzo de los particulares, se derribo aqui, se edificó más allá, se movieron terrenos, se trasplanta. ron árboles $\mathrm{y}$ en pocos años lo que ántes era camino bo brego y fangoso, cercado do tapias oscuras y edificios de triste aspecto, se convirtió en magnificos paseos bordados de jardines y palacios que se prolongan hasta el obeliseo de la Castellana, meta colocada al extremo del espacio en que se agita el mundo elegante.

Entre estos palacios modernos, uno de los más nots. bles por sus proporciones, el lujo desplegado en su cons. truccion y la completa idea que por el puede formase del gusto dominante en la arquitectira urbana de nuestra época, es del duque de Uceda, del cual ofrecemos un exacto dibujo en nuestras columnas.

\section{IIOBLE, CABALLO DE LA PROPIEADD} DEL SENTOR MARQUÚS DE VALLE UMBROSO.

Decididos á dar cabida en nuestras columnas a cuan. to puede excitar la curiosidad $\sigma$ el interés del públiso, ofrecemos hoy la reproduccion de una fotografia hecha por el Sr. Laurent, del caballo Noble, que por sus inmejorables cualidades de raza y estampa, est $l 1$ lamando la atencion de los inteligentes.

IMPREXTA DE BA. IMPARCIAL, PLAZA DE MATUTE, 5

Figura 5. Texto de Rosalía de Castro, «D. Juan Valera Alcalá Galiano» (continuación) e outros comentarios de gravados sen sinatura. La Ilustración de Madrid (I2/2/1870: I6). 